\title{
ANALISIS PENGARUH CITRA PRODUK TERHADAP KEPUTUSAN PEMBELIAN SABUN CUCI PAKAIAN RINSO PADA MAHASISWA/I PERGURUAN TINGGI DI BOGOR
}

\author{
Mohammad Argya \\ Sekolah Tinggi Ekonomi Islam Tazkia Bogor, Program Studi Majanemen \\ Pemasaran Islam.
}

Email: argy.moh@gmail.com

\begin{abstract}
The purpose of this study is to know how big the influence of Brand Image Detergent Rinso of purchase decision on students of STEI Tazkia, Pakuan University and Djuanda University in Bogor. The method used in this study is multiple regression methods to see the influence of the Brand Image of Detergent Rinso purchase decisions and use the correlation coefficient to see how much the influence brand image of Detergent Rinso purchase decision on students of STEI Tazkia, Pakuan University and Djuanda in Bogor. Based on the analysis, known that the influence of the Brand Image of Detergent Rinso purchase decisions classified as strong enough seen from the values of $r=0,642$. In addition, based on the calculated correlation coefficient demonstrate the value of rsquare = 0,412, shows that for 41,2\% purchasing of Detergent Rinso are influenced by a Brand Image while the remaining 58,8\% influenced by other factors is not examined.
\end{abstract}

Keyword: Brand Image, Purchasing Decisions

\section{Pendahuluan}

Pembangunan yang dilakukan di Indonesia pada saat ini semakin meningkat, disertai dengan pesatnya tingkat kemajuan ilmu pengetahuan dan teknologi, hal tersebut akan berpengaruh terhadap peningkatan ekonomi masyarakat. Secara tidak langsung perubahan tersebut dapat mendorong perusahaan-perusahaan yang ada untuk dapat bersaing dan menggiatkan usahanya demi mencapai target yang diinginkan. Tujuan atau target perusahaan yang utama adalah memiliki posisi dalam persaingan dan memperoleh keuntungan yang optimal.

Berbagai macam produk baru bermunculan mengikuti arus kebutuhan persaingan pasar, tidak jarang ada beberapa produsen menghasilkan produk yang memang benar-benar baru dan ada juga produk yang dihasilkan adalah produk recycle atau daur ulang yaitu menciptakan kembali produk yang sudah ada dengan sedikit modifikasi. Dalam setiap jenis usaha, perusahaan diharapkan bias menghasilkan produk yang memiliki dayaa tarik atau ciri khas tersendiri, baik dari segi kemasannya atau dari cita rasa produk tersebut. Selain itu, perusahaan juga 
dituntut untuk melakukan pemberian merek atau branding terhadap produk yang dihasilkannya agar konsumen dapat lebih mudah untuk membedakan produk tersebut dengan produk lain.

Citra produk merupakan prioritas utama yang dijadikan acuan bagi konsumen sebelum melakukan pembelian, oleh karena itu perusahaan harus dapat menciptakan suatu merek yang menarik dan menggambarkan manfaat produk yang sesuai dengan keinginan konsumen, sehingga konsumen memiliki peresepsi yang positif terhadap merek tersebut. Citra produk yang baik merupakan salah satu aset bagi perusahaan karena brand mempunyai suatu dampak pada setiap persepsi konsumen, dimana masyarakat akan mempunyai kesan positif terhadap perusahaan

Salah satu perusahaan yang melakukan penciptaan citra produk yang positif adalah PT. UNILEVER Tbk. Kekuatan utama PT Unilever terletak pada visi pemasaran yang terfokus terus-menerus membangun merek yang kuat dan memperlebar ragam produk kebutuhan sehari-hari untuk memenuhi kebutuhan konsumen Indonesia. Salah satu strategi pemasaran yang dilakukan oleh PT Unilever adalah strategi penciptaan merek, dengan merek yang telah ada maka akan menciptakan image yang positif di benak konsumen.

Salah satu produk yang dipasarkan oleh PT Unilever adalah RINSO yaitu sabun cuci pakaian yang telah dikenal sejak lama oleh masyarakat Indonesia, sejak Unilever memasuki Indonesia pada tahun 1930-an. Citra produk yang kuat menjadi salah satu hal yang ditonjolkan oleh PT Unilever, selain itu strategi yang dilaksanakan oleh PT Unilever adalah melakukan penelitian yang berkesinambungan mengenai aspirasi dan animo pasar, melakukan difersifikasi dan pengembangan produk untuk mempertahankan pangsa pasar, melakukan penerapan strategi pemasaran yang tepat serta penerapan teknik distribusi yang efisien dan tepat sasaran. (www.rinso.co.id)

Dengan adanya citra produk yang positif, maka diharapkan konsumen akan lebih mudah untuk dapat melakukan suatu keputusan pembelian dimana seseorang konsumen akan dipengaruhi oleh faktor-faktor kejiwaan dan faktor luar lainnya yang mengarahkan mereka untuk memilih dan mempergunakan barang/jasa yang diinginkannya. Perilaku konsumen terhadap suatu produk dapat dipengaruhi oleh beberapa faktor, salah satunya adalah keyakinan terhadap produk tertentu yang tertanam pada citra produk yang baik, sehingga konsumen tersebut akan mengambil keputusan untuk melakukan pembelian produk tersebut.

Berdasarkan latar belakang penelitian tersebut diatas, maka penulis sangat tertarik untuk membahas dan melakukan penelitian dengan judul "Analisis Pengaruh Citra Produk Terhadap Keputusan Pembelian Sabun Cuci Pakaian RINSO Pada Mahasiswa/i Perguruan Tinggi di Bogor. 


\section{Tinjauan Pustaka}

\subsection{Produk Berdasarkan Syariah}

Sebuah produk dan atau jasa yang diproduksi oleh produsen harus memenuhi kriteria halal dan thayyibah serta tidak mengandung unsur yang merugikan konsumen. Tetapi seorang konsumen juga harus mencari informasi dan meneliti terlebih dahulu tentang produk dan atau jasa yang akan dia konsumsi. Sebagaimana disebutkan dalam Al-Qur'an surat Al-A'raf ayat 157:

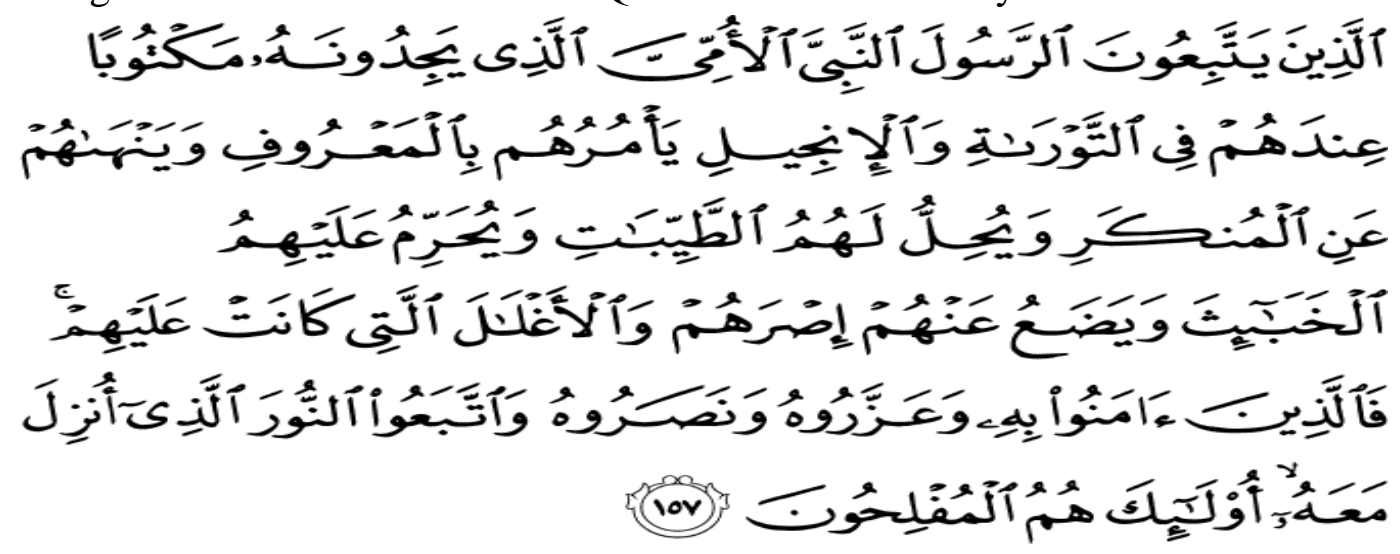

Artinya:

(Yaitu) orang-orang yang mengikut Rasul, Nabi yang ummi yang (namanya) mereka dapati tertulis di dalam Taurat dan Injil yang ada di sisi mereka, yang menyuruh mereka mengerjakan yang mâ̂'ruf dan melarang mereka dari mengerjakan yang mungkar dan menghalalkan bagi mereka segala yang baik dan mengharamkan bagi mereka segala yang buruk dan membuang dari mereka beban-beban dan belenggu-belenggu yang ada pada mereka. Maka orang-orang yang beriman kepadanya. memuliakannya, menolongnya dan mengikuti cahaya yang terang yang diturunkan kepadanya (Al Quran), mereka itulah orang-orang yang beruntung. (Al-A'raf:157)

\subsection{Pemasaran}

Menurut Kotler (2004), bauran pemasaran (marketing mix) adalah seperangkat alat pemasaran yang digunakan oleh perusahaan untuk terus-menerus mencapai tujuan pemasarannya di pasar sasaran.

Menurut Ad. Payne (1995), pengertian bauran pemasaran adalah unsur atau elemen internal penting yang membentuk program pemasaran sebuah organisasi. Bauran pemasaran merupakan salah satu konsep universal yang telah dikembangkan dalam pemasaran.

Menurut Stanton (2001) Bauran Pemasaran (Marketing Mix) adalah kombinasi dari empat variabel atau kegiatan yang merupakan inti dari sistem pemasaran perusahaan yaitu produk, harga, kegiatan promosi dan sistem distribusi.

Unsur-unsur dari variabel pemasaran tersebut adalah: 
1. Produk (Product)

2. Harga (Price)

3. Distribusi (Place)

4. Promosi (Promotion)

Dari definisi tersebut diatas bauran pemasaran adalah seperangkat alat pemasaran dan elemen internal penting yang digunakan sebuah perusahaan dan atau organisasi untuk mendukung program pemasarannya mencapai sebuah tujuan yang diinginkan.

\subsection{Citra Produk}

Menurut Kotler (2001), citra produk adalah pemahaman konsumen mengenai merek secara keseluruhan, yang mudah dimengerti tetapi sulit dijelaskan secara sistematis karena sifatnya abstrak.

Menurut Ouwersoot dan Tudorica, (2001), citra produk adalah kumpulan persepsi tentang sebuah merek yang saling berkaitan yang ada dalam pikiran manusia.

Menurut Keller (1998), citra produk adalah persepsi tentang merek yang digambarkan oleh asosiasi merek yang ada dalam ingatan konsumen.

Dari berbagai pengertian tersebut, citra produk adalah pemahaman atau persepsi konsumen tentang suatu merek yang digambarkan oleh asosiasi merek yang mudah dimengerti dan ada dalam ingatan serta pikiran konsumen tetapi sulit untuk dijelaskan secara sistematis dikarenakan sifatnya yang abstrak.

Menurut Kotler (2008), merek merupakan janji penjual untuk secara konsisten memeberikan manfaat dan jasa tertentu pada pembeli. Merek-merek terbaik merupakan jaminan kualitas, diungkapkan bahwa merek dapat memiliki enam tingkat pengertian, yaitu:

1. Atribut, setiap merek memiliki atribut. Atribut ini perlu dikelola dan diciptakan agar konsumen dapat mengetahui dengan pasti atribut-atribut apa saja yang terkandung dalam suatu merek.

2. Manfaat (benefit) suatu merek lebih dari sekedar atribut. Konsumen tidak membeli atribut tapi lebih membeli manfaat yang terdapat dalam suatu produk. Atribut diperlukan jika hanya untuk diterjemahkan menjadi manfaat fungsional.

3. Nilai (value), merek menguatkan sesuatu tentang nilai bagi suatu produk. Merek yang memiliki nilai tinggi akan dapat lebih dihargai oleh konsumen sebagai merek yang berkelas, sehingga dapat mencerminkan siapa pengguna merek tersebut. 
4. Budaya (culture), merek memiliki budaya tertentu seperti budaya negara yang terorganisasi produk yang berkualitas dan kinerja yang efisien.

5. Kepribadian, merek memiliki kepribadian bagi para penggunanya dimana dengan menggunakan merek tersebut pengguna akan tercermin bersamaan dengan merek yang mereka inginkan.

6. Pemakai, merek menunjukan jenis konsumen yang membeli dan mengkonsumsi.

\subsection{Keputusan Pembelian}

Menurut Kotler (2001), pengertian keputusan pembelian adalah tahap dalam proses pengambilan keputusan dimana konsumen benar-benar membeli. Pengambilan keputusan merupakan suatu kegiatan individu yang secara langsung terlibat dalam mendapatkan dan mempergunakan barang yang ditawarkan.

Menurut Kotler (1999), proses keputusan pembelian merupakan suatu perilaku konsumen untuk menentukan suatu proses pengembangan keputusan dalam membeli suatu produk. Proses tersebut merupakan sebuah penyelesaian masalah harga yang terdiri dari lima tahap. Lima tahap proses keputusan pembelian tersebut adalah:

1. Pengenalan Masalah

Merupakan tahap pertama diproses keputusan pembelian dimana konsumen mengenali masalah atau kebutuhan.

2. Pencarian Informasi

Pada tahap ini konsumen digerakkan untuk mencari lebih banyak informasi, Konsumen bisa lebih mudah melakukan pencarian informasi aktif, ketika lebih banyak informasi diperoleh maka kesadaran dan pengetahuan konsumen tentang barang atau jasa akan semakin meningkat.

3. Penilaian Alternatif

Konsumen menggunakan informasi untuk mengevaluasi merekmerek alternative dalam himpunan pikiran.

4. Keputusan Pembelian Pada tahap ini konsumen secara actual membeli suatu produk.

5. Perilaku Pasca Pembelian

Setelah pembelian produk, konsumen akan mengalami suatu tingkat kepuasan atau ketidakpuasan tertentu. Jika produk sesuai harapan maka konsumen puas. Jika melebihi harapan maka konsumen sangat puas. Jika kurang memenuhi harapan maka konsumen tidak puas. Kepuasan atau ketidakpuasan konsumen dengan suatu produk akan mempengaruhi perilaku selanjutnya. Bila konsumen puas, dia akan menunjukkan probabilitas yang lebih tinggi untuk membeli produk itu lagi. 
Dari definisi diatas dapat disimpulkan bahwa proses keputus pembeli adalah sebuah proses dimana konsumen memutuskan untuk membeli suatu produk berdasarkan dari beberapa pertimbangan dan tahapan. Dimana kegiatan tersebut membawa konsumen memenuhi kebutuhannya dan mendapatkan tingkat kepuasan.

\subsection{Penelitian Terdahulu}

Berikut ini adalah beberapa penelitian yang telah dilakukan sebelumnya yang berkaitan dengan proses keputusan pembelian konsumen berdasarkan citra produk (citra produk):

Tuti Budiarti (Universitas Hasanuddin, 2012) dalam penelitiannya yang berjudul "Pengaruh Citra Merek Terhadap Pengambilan Keputusan Pembelian Motor Kawasaki Pada PT. Diana Indonesia di Makassar" menunjukkan bahwa berdasarkan pengujian secara serempak/simultan (Uji F), ternyata hasil penelitian membuktikan bahwa semua variabel citra merek (Atribut, Kepribadian, dan Manfaat) dari variabel citra merek secara simultan mempunyai pengaruh yang signifikan terhadap variabel dependen, yaitu Keputusan Pembelian. Dan, berdasarkan analisis secara parsial (Uji t), ternyata hasil penelitian membuktikan bahwa semua variabel dari variabel independen citra merek (citra produk), yaitu Atribut, Kepribadian, dan Manfaat mempunyai pengaruh positif dan signifikan terhadap variabel dependen yaitu keputusan pembelian motor Kawasaki pada PT. Diana Indonesia di Makassar. Sedangkan hasil penelitian yang penulis lakukan menyatakan bahwa satu dari empat variabel independen yaitu Atribut tidak berpengaruh terhadap Keputusan Pembelian RINSO, sedangkan tiga variabel lainnya yaitu Manfaat, Nilai dan Budaya mempunyai pengaruh positif dan signifikan terhadap Keputusan Pembelian RINSO.

Ria Fitriani (Universitas Widyatama, 2007) dalam penelitiannya yang berjudul "Pengaruh Citra produk Ultramilk Terhadap Proses Keputusan Pembelian Konsumen (Survey pada Mahasiswa Universitas Widyatama)" menunjukkan bahwa berdasarkan perhitungan dengan menggunakan metode statistik yaitu dengan Analisis Korelasi Rank Spearman, dapat diketahui bahwa variabel dari citra merek (Atribut, Manfaat dan Nilai) berpengaruh secara parsial dan simultan terhadap proses keputusan pembelian. Sedangkan hasil penelitian yang penulis lakukan menyatakan bahwa satu dari empat variabel independen yaitu Atribut tidak berpengaruh terhadap Keputusan Pembelian RINSO, sedangkan tiga variabel lainnya yaitu Manfaat, Nilai dan Budaya mempunyai pengaruh positif dan signifikan terhadap Keputusan Pembelian RINSO.

Thomas Bayu (Universitas Widyatama, 2007) dalam penelitiannya yang berjudul "Pengaruh Citra produk Terhadap Keputusan Pembelian Konsumen Pada Produk Motor Honda (Studi Kasus Pada PD. Sinar Karya Bandung)”. Penelitian 
ini menggunakan metode satistik Analisa Korelasi Rank Spearman dan Pengujian Hipotesis. Sedangkan hasil penelitian yang penulis lakukan menyatakan bahwa satu dari empat variabel independen yaitu Atribut tidak berpengaruh terhadap Keputusan Pembelian RINSO, sedangkan tiga variabel lainnya yaitu Manfaat, Nilai dan Budaya mempunyai pengaruh positif dan signifikan terhadap Keputusan Pembelian RINSO.

Jurnal dengan judul "Pengaruh Perilaku Konsumen Mobile Internet Terhadap Keputusan Pembelian Paket Layanan Data Unlimited Internet CDMA di DKI Jakarta" yang ditulis oleh Handy Noviarto, 2010. Hasil penelitian ini menunjukan responden tertinggi untuk konsumen mobile internet untuk menggunakan layanan unlimited adalah dengan melakukan akses internet untuk situs berita dengan presentase $24 \%$ dan situs jejaring sosial 23\% dan yang prosentase terendah 5\% untuk akses lainnya, seperti search engine sehingga ada hubungan yang positif dengan uraian di dalam penelitian ini.

Jurnal dengan judul "Pengaruh Citra Merek dan Kualitas Produk Terhadap Keputusan Pembelian Produk PT. Karya Pak Oles Tokcer Denpasar" yang ditulis oleh Ni Putu Novia Karlina. Hasil penelitian ini menunjukan berdasarkan klarifikasi karakteristik responden, responden laki laki lebih banyak yang mengambil keputusan pembelian produk PT. Karya Pak Oles Tokcer Denpasar yakni sebesar 58\% jika dibandingkan dengan responden perempuan berjumlah $48 \%$. Dilihat dari karakteristik umur, mayoritas responden yang berumur $>34-44$. Pada karakteristik pendidikan akhir responden, mayoritas responden berpendidikan akhir SMA/K.

\section{Metodologi Penelitian}

\subsection{Sumber dan Jenis Penelitian}

Jenis dan sumber data yang digunakan dalam penelitian ini adalah data kuantitatif. Menurut Sugiono (2008), metode kuantitatif adalah pendekatan ilmiah yang memandang suatu realitas itu dapat diklasifikasikan,konkrit,teramati dan terukur,hubungan variabelnya bersifat sebab akibat dimana data penelitiannya berupa angka-angka dan analisisnya menggunakan statistik.Untuk mengetahui tanggapan responden, teknik yang digunakan oleh penulis adalah penelitian lapangan (Field Research) dengan menggunakan kuesioner.

Pada dasarnya kuesioner sebagai salah satu alat instrumen penelitian yang merupakan sebuah daftar pertanyaan yang harus diisi oleh orang yang akan diteliti atau disebut responden. Menurut Arikunto (2006), kuesioner adalah sejumlah pertanyaan tertulis yang digunakan untuk memperoleh informasi dari responden dalam arti laporan tentang pribadinya atau hal-hal yang diketahuinya. 


\subsection{Metode Analisis Data}

Metode analisis data pada penelitian ini yaitu menggunakan metode regresi linier berganda. Dalam melakukan analisis regresi linier berganda, metode ini mengisyaratkan untuk melakukan uji asumsi klasik agar mendapatkan hasil regresi yang baik (Ghozali, 2005).

Regresi linear berganda adalah regresi linear yang memiliki lebih dari satu variabel independen (bebas) (Suharyadi, 2004). Bentuk umum persamaan regresi untuk variabel independen dapat dirumuskan sebagai berikut:

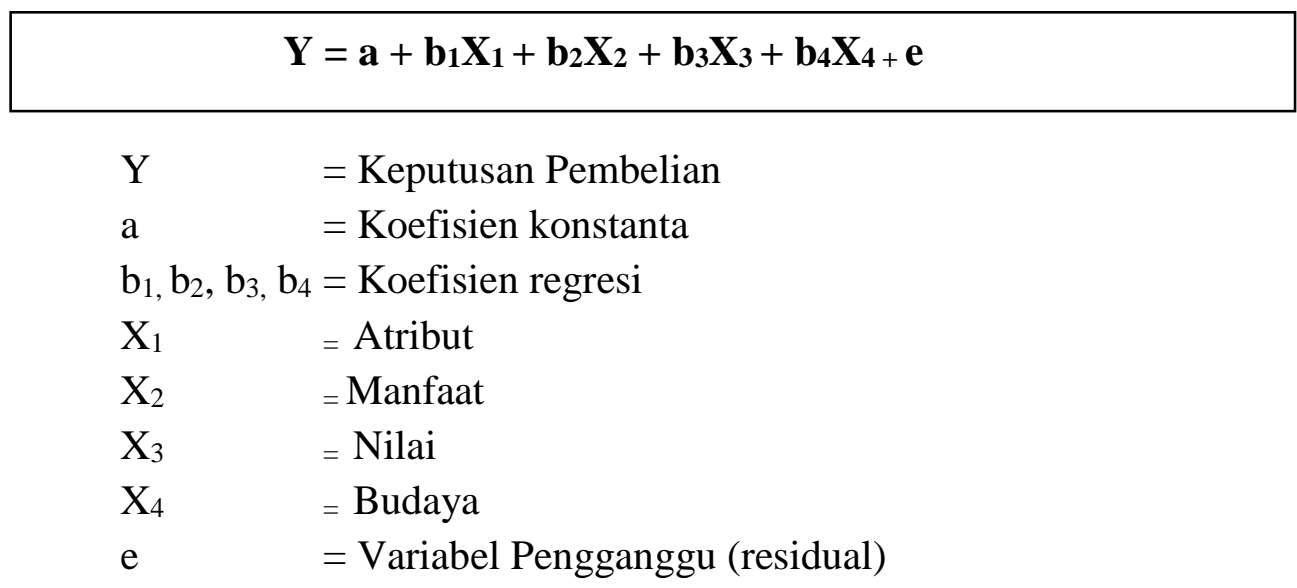

\subsection{Kerangka Penelitian}

Dalam penelitian ini, yang merupakan variabel independen dari Citra produk adalah Atribut, Manfaat, Nilai, Budaya. Sedangkan yang menjadi variabel dependen adalah Proses Keputusan Pembelian Konsumen. Berdasarkan uraian diatas, kerangka pemikiran dapat digambarkan sebagai berikut:

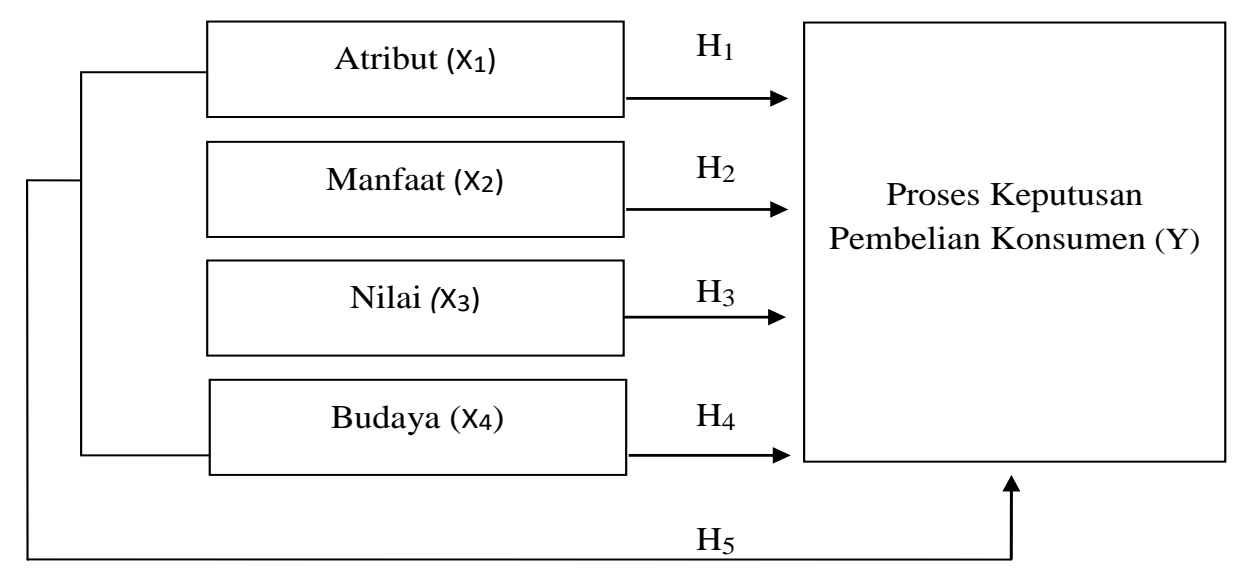

Gambar 1. Kerangka Pemikiran

Sumber: Olah Data Peneliti 


\subsection{Definisi Operasional Variabel}

Variabel operasional dalam penelitian ini adalah Atribut, Manfaat, Nilai dan Budaya, kemudian variabel akan diukur berdasarkan proses keputusan pembelian konsumen (Variabel Y).

Tabel 1. Definisi Operasional Variabel Bebas

\begin{tabular}{|c|c|c|c|}
\hline Jenis Variabel & Sub-Variabel & Indikator & Skala \\
\hline \multirow[t]{4}{*}{$\begin{array}{l}\text { Citra produk adalah } \\
\text { pemahaman konsumen } \\
\text { mengenai produk } \\
\text { secara keseluruhan, } \\
\text { yang mudah } \\
\text { dimengerti tetapi sulit } \\
\text { dijelaskan secara } \\
\text { sistematis karena } \\
\text { sifatnya abstrak. } \\
\text { (Kotler, 2001) }\end{array}$} & - Atribut & $\begin{array}{l}\text { 1. Nama } \\
\text { merek } \\
\text { mudah } \\
\text { diingat dan } \\
\text { diucapkan } \\
\text { 2. Logo yang } \\
\text { mudah } \\
\text { diingat } \\
\text { 3. Kualitas } \\
\text { produk }\end{array}$ & Skala Likert \\
\hline & - Manfaat & $\begin{array}{l}\text { 1. Merek } \\
\text { melekat } \\
\text { dalam benak } \\
\text { konsumen } \\
\text { 2. Produk } \\
\text { yang } \\
\text { bermanfaat }\end{array}$ & Skala Likert \\
\hline & - Nilai & $\begin{array}{l}\text { 1. Kesesuaian } \\
\text { harga } \\
\text { dengan } \\
\text { kualitas } \\
\text { produk }\end{array}$ & Skala Likert \\
\hline & - Budaya & $\begin{array}{l}\text { 1. Produk } \\
\text { yang } \\
\text { menyehatka } \\
\text { n dan } \\
\text { dianjurkan }\end{array}$ & Skala Likert \\
\hline
\end{tabular}

Sumber: Olah Data Penelliti 
Tabel 2. Definisi Operasional Variabel Terikat

\begin{tabular}{|c|c|c|c|}
\hline Jenis Variabel & Sub-Variabel & Indikator & Skala \\
\hline \multirow[t]{5}{*}{$\begin{array}{l}\text { Keputusan } \\
\text { pembelian } \\
\text { adalah tahap } \\
\text { dalam proses } \\
\text { pengambilan } \\
\text { keputusan } \\
\text { dimana } \\
\text { konsumen benar- } \\
\text { benar membeli. } \\
\text { (Kotler, 2001). }\end{array}$} & $\begin{array}{l}\text { Pengenalan } \\
\text { Masalah }\end{array}$ & $\begin{array}{l}\text { Tahap pertama } \\
\text { diproses } \\
\text { keputusan } \\
\text { pembelian } \\
\text { dimana } \\
\text { konsumen } \\
\text { mengenali } \\
\text { masalah atau } \\
\text { kebutuhan. }\end{array}$ & Skala Likert \\
\hline & $\begin{array}{ll}- & \text { Pencarian } \\
& \text { Informasi }\end{array}$ & $\begin{array}{l}\text { Tahap ini } \\
\text { konsumen } \\
\text { digerakkan } \\
\text { untuk mencari } \\
\text { lebih banyak } \\
\text { informasi }\end{array}$ & Skala Likert \\
\hline & $\begin{array}{ll}- & \text { Penilaian } \\
& \text { Alternatif }\end{array}$ & $\begin{array}{l}\text { Konsumen } \\
\text { menggunakan } \\
\text { informasi } \\
\text { untuk } \\
\text { mengevaluasi } \\
\text { merek-merek } \\
\text { alternatif dalam } \\
\text { himpunan } \\
\text { pikiran } \\
\end{array}$ & Skala Likert \\
\hline & $\begin{array}{ll}- & \text { Keputusan } \\
& \text { Pembelian }\end{array}$ & $\begin{array}{l}\text { Tahap ini } \\
\text { konsumen } \\
\text { secara actual } \\
\text { membeli suatu } \\
\text { produk }\end{array}$ & Skala Likert \\
\hline & $\begin{array}{ll}\text { - } & \text { Perilaku } \\
\text { Pasca } \\
\text { Pembelian }\end{array}$ & $\begin{array}{l}\text { Kepuasan atau } \\
\text { ketidakpuasan } \\
\text { konsumen } \\
\text { dengan suatu } \\
\text { produk akan } \\
\text { mempengaruhi } \\
\text { perilaku } \\
\text { selanjutnya }\end{array}$ & Skala Likert \\
\hline
\end{tabular}

Sumber: Olah Data Peneliti 


\subsection{Hipotesis}

Menurut Erlina (2008:49) "Hipotesis adalah proporsi yang dirumuskan dengan maksud untuk diuji secara empiris". Hipotesis menyatakan hubungan yang diduga secara logis antara dua variabel atau lebih dalam rumusan proporsi yang dapat diuji secara empiris. Hipotesis merupakan jawaban sementara dari penelitian yang akan dilakukan.

Hipotesis yang dirumuskan dalam penelitian ini adalah :

1. Ada hubungan antara Atribut dengan Keputusan Pembelian.

2. Ada hubungan antara Manfaat dengan Keputusan Pembelian.

3. Ada hubungan antara Nilai dengan Keputusan Pembelian.

4. Ada hubungan antara Budaya dengan Keputusan Pembelian.

5. Ada hubungan antara Atribut, Manfaat, Nilai, Budaya dengan Keputusan Pembelian.

\section{Hasil dan Pembahasan}

\subsection{Deskripsi Responden}

Tabel 3. Klasifikasi Responden Berdasarkan Asal Universitas

\begin{tabular}{|l|c|c|}
\hline \multicolumn{1}{|c|}{ Keterangan } & Jumlah & Persentase \\
\hline STEI Tazkia & 83 & $31 \%$ \\
\hline Universitas Pakuan & 93 & $35 \%$ \\
\hline Universitas Juanda & 91 & $34 \%$ \\
\hline Total & 267 & $100 \%$ \\
\hline
\end{tabular}

Berdasarkan tabel 3 di atas, dari 267 responden yang menjadi objek penelitian adalah 83 responden (31\%) berasal dari STEI Tazkia, 93 responden (35\%) berasal dari Universitas Pakuan, 91 responden (34\%) berasal dari Universitas Juanda. Dari segi aspek marketing responden yang paling tinggi berasal dari Universitas Pakuan karena tingkat popularitas di kota dan kabupaten Bogor lebih dikenal dikalangan masyarakat. 
AL-INFAQ: Jurnal Ekonomi Islam, (p-ISSN: 2087-2178, e-ISSN: 2579-6453)

Vol. 9 No. 2, December 2018

Tabel 4. Klasifikasi Responden Berdasarkan Pendapatan Perbulan

\begin{tabular}{|l|c|c|}
\hline \multicolumn{1}{|c|}{ Keterangan } & Jumlah & Persentase \\
\hline $500.000-1.000 .000$ & 48 & $18 \%$ \\
\hline $1.000 .001-1.500 .000$ & 31 & $12 \%$ \\
\hline $1.500 .001-2.000 .000$ & 59 & $22 \%$ \\
\hline$\geq 2.000 .000$ & 129 & $48 \%$ \\
\hline Total & 267 & $100 \%$ \\
\hline
\end{tabular}

Sumber: Data kuesioner yang telah diolah

Tabel 4 menunjukkan bahwa Sabun Cuci Rinso menyasar segmen individu dengan pendapatan perbulan Rp. 2.000.000 ke atas. Hal tersebut dibuktikan dari 267 responden, sebanyak 48\% atau 129 responden merupakan individu yang memiliki pendapatan perbulan Rp. 2.000 .000 ke atas.

Tabel 4 juga menunjukan bahwa sebanyak 22\% atau 59 responden memiliki pendapatan perbulan sebesar Rp.1.500.001 sampai dengan Rp.2.000.000. Kemudian terdapat $18 \%$ atau 48 responden memiliki pendapatan perbulan sebesar Rp. 500.000 sampai dengan Rp. 1.000.000. Dan terakhir, hanya 31 responden (12\%) yang memiliki pendapatan perbulan sebesar Rp. 1.000.001 sampai dengan Rp. 1.500.000.

\subsection{Uji Validitas dan Reliabilitas}

1. Uji Validitas

Dalam penelitian ini, semua instrumen kuesioner (no. 1-10) terhadap variabel brand image (X) adalah valid. Hal tersebut ditunjukkan oleh r Product Moment Hitung lebih besar dari $r$ Product Moment Tabel $(0,195)$. Tabel 5 dibawah menjelaskan uji validitas terhadap variabel brand image (X).

Tabel 5. Uji Validitas Terhadap Variabel X (Brand Image)

\begin{tabular}{|c|c|c|c|c|}
\hline $\begin{array}{c}\text { No. } \\
\text { Soal }\end{array}$ & $\begin{array}{c}\text { r Product Moment } \\
\text { Hitung }\end{array}$ & $\begin{array}{c}\text { r Product Moment } \\
\text { Tabel }(\mathrm{n}=100, \alpha=5 \%)\end{array}$ & Kesimpulan \\
\hline 1 & 0,483 & 0,195 & 0,000 & Valid \\
\hline 2 & 0,520 & 0,195 & 0,000 & Valid \\
\hline 3 & 0,567 & 0,195 & 0,000 & Valid \\
\hline 4 & 0,517 & 0,195 & 0,000 & Valid \\
\hline 5 & 0,527 & 0,195 & 0,000 & Valid \\
\hline 6 & 0,524 & 0,195 & 0,000 & Valid \\
\hline 7 & 0,571 & 0,195 & 0,000 & Valid \\
\hline 8 & 0,624 & 0,195 & 0,000 & Valid \\
\hline 9 & 0,559 & 0,195 & 0,000 & Valid \\
\hline 10 & 0,639 & 0,195 & 0,000 & Valid \\
\hline
\end{tabular}

Sumber: Data kuesioner yang telah diolah 
Penelitian ini juga menunjukan bahwa semua instrumen kuesioner (no. 18) terhadap variabel keputusan pembelian (Y) adalah valid. Hal tersebut ditunjukkan oleh $r$ Product Moment Hitung lebih besar dari r Product Moment Tabel $(0,195)$. Tabel 6 dibawah menjelaskan uji validitas terhadap variabel keputusan pembelian (Y).

Tabel 6. Uji Validitas Terhadap Variabel Y (Keputusan Pembelian)

\begin{tabular}{|c|c|c|c|c|}
\hline $\begin{array}{c}\text { No. } \\
\text { Soal }\end{array}$ & $\begin{array}{c}\text { r Product Moment } \\
\text { Hitung }\end{array}$ & $\begin{array}{c}\mathrm{r} \text { Product Moment } \\
\text { Tabel }(\mathrm{n}=100, \alpha=5 \%)\end{array}$ & Kesimpulan \\
\hline 1 & 0,653 & 0,195 & 0,000 & Valid \\
\hline 2 & 0,620 & 0,195 & 0,000 & Valid \\
\hline 3 & 0,688 & 0,195 & 0,000 & Valid \\
\hline 4 & 0,389 & 0,195 & 0,000 & Valid \\
\hline 5 & 0,728 & 0,195 & 0,000 & Valid \\
\hline 6 & 0,721 & 0,195 & 0,000 & Valid \\
\hline 7 & 0,651 & 0,195 & 0,000 & Valid \\
\hline 8 & 0,615 & 0,195 & 0,000 & Valid \\
\hline
\end{tabular}

Sumber: Data kuesioner yang telah diolah

\section{Uji Reliabilitas}

Pada penelitian ini, uji reliabilitas terhadap variabel $\mathrm{x}$ dan y ditunjukkan oleh tabel 7 sebagai berikut.

Tabel 7. Uji Reliabilitas Terhadap Variabel X dan Y

\begin{tabular}{|r|r|r|}
\hline $\begin{array}{c}\text { Cronbach's } \\
\text { Alpha }\end{array}$ & $\begin{array}{c}\text { Cronbach's } \\
\text { Alpha Based on } \\
\text { Standardized } \\
\text { Items }\end{array}$ & N of Items \\
\hline, 568 &, 723 & \\
\hline
\end{tabular}

Berdasarkan tabel 7 diatas, dimana suatu reliabel dinyatakan valid apabila memberikan nilai Cronbach's Alpha $>0,60$. Dalam penelitian ini, reliabilitas variabel $\mathrm{X}$ terhadap variabel $\mathrm{Y}$ dinyatakan valid, karena Cronbach's Alpha $(0,723)>0,60$.

\subsection{Uji Regresi}

Untuk menganalisa pengaruh variabel independen terhadap variabel dependen dapat dilakukan dengan model analisis regresi linear berganda. Analisis regresi ini dimaksudkan untuk mengetahui ada tidaknya pengaruh variabel independen (Atribut, Nilai, Manfaat dan Budaya) terhadap variabel dependen 
(Keputusan Pembelian). Dengan itu digunakan Multiple Linear Regression (Regresi Linear Berganda) dengan rumus: (Manurung, 2005).

$$
Y=a+b_{1} X_{1}+b_{2} X_{2}+b_{3} X_{3}+b_{4} X_{4} e
$$

Dimana :

$$
\begin{array}{ll}
\mathrm{Y} & =\text { Keputusan Pembelian } \\
\mathrm{a} & =\text { Koefisien konstanta } \\
\mathrm{b}_{1}, \mathrm{~b}_{2}, \mathrm{~b}_{3}, \mathrm{~b}_{4} & =\text { Koefisien regresi } \\
\mathrm{X}_{1} & =\text { Atribut } \\
\mathrm{X}_{2} & =\text { Manfaat } \\
\mathrm{X}_{3} & =\text { Nilai } \\
\mathrm{X}_{4} & =\text { Budaya } \\
e & =\text { Variabel Pengganggu (residual) }
\end{array}
$$

\begin{tabular}{|c|c|c|c|c|c|c|}
\hline \multirow{2}{*}{\multicolumn{2}{|c|}{ Model }} & \multicolumn{2}{|c|}{$\begin{array}{c}\text { Unstandardized } \\
\text { Coefficients } \\
\end{array}$} & \multirow{2}{*}{$\begin{array}{l}\begin{array}{l}\text { Standardized } \\
\text { Coefficients }\end{array} \\
\text { Beta }\end{array}$} & \multirow[t]{2}{*}{$\mathrm{t}$} & \multirow[t]{2}{*}{ Sig. } \\
\hline & & B & Std. Error & & & \\
\hline \multirow{6}{*}{1} & (Constant & 4,931 & ,931 & & 5,299 &, 000 \\
\hline & ) & & & & & \\
\hline & X_1 & ,383 & ,059 & ,385 & 6,441 & ,000 \\
\hline & X_2 & ,308 & , 105 & , 166 & 2,926 &, 004 \\
\hline & X_3 & ,082 & ,094 &, 052 &, 874 & ,383 \\
\hline & X_4 & ,336 & ,116 & ,184 & 2,898 & ,004 \\
\hline
\end{tabular}

Tabel 8. Uji Regresi Berganda

\section{Coefficients $^{\mathrm{a}}$}

a. Dependent Variable: Y

Berdasarkan tabel diatas dapat diperoleh rumus regresi sebagai berikut:

$$
\hat{Y}=4,931+0,383 X 1+0,308 X 2+0,082 X 3+0,336 X 4+e
$$

Interpretasi dari regresi diatas adalah sebagai berikut:

a) Konstanta (a)

Ini berarti jika semua variabel bebas memiliki nilai nol (0) maka nilai variabel terikat (Keputusan Pembelian) sebesar 4,931.

b) Atribut $\left(\mathrm{X}_{1}\right)$ terhadap Keputusan Pembelian (Y) 
Nilai koefisien Atribut untuk variabel $\mathrm{X}_{1}$ sebesar 0,383. Hal ini mengandung arti bahwa setiap kenaikan Atribut satu satuan maka variabel Keputusan Pembelian (Y) akan naik sebesar 0,383 dengan asumsi bahwa variabel bebas yang lain dari model regresi adalah tetap.

c) Manfaat $\left(\mathrm{X}_{2}\right)$ terhadap Keputusan Pembelian (Y)

Nilai koefisien Manfaat untuk variabel $\mathrm{X}_{2}$ sebesar 0,308 dan bertanda positif, ini menunjukkan bahwa Manfaat mempunyai hubungan yang searah dengan Keputusan Pembelian. Hal ini mengandung arti bahwa setiap kenaikan Manfaat satu satuan maka variabel Keputusan Pembelian (Y) akan naik sebesar 0,308 dengan asumsi bahwa variabel bebas yang lain dari model regresi adalah tetap.

d) Nilai $\left(\mathrm{X}_{3}\right)$ terhadap Keputusan Pembelian (Y)

Nilai koefisien Nilai untuk variabel $\mathrm{X}_{3}$ sebesar 0,082 dan bertanda positif, ini menunjukkan bahwa Nilai mempunyai hubungan yang searah dengan Keputusan Pembelian. Hal ini mengandung arti bahwa setiap kenaikan Nilai satu satuan maka variabel Keputusan Pembelian (Y) akan naik sebesar 0,082 dengan asumsi bahwa variabel bebas yang lain dari model regresi adalah tetap.

e) Budaya $\left(\mathrm{X}_{4}\right)$ terhadap Keputusan Pembelian (Y)

Nilai koefisien Budaya untuk variabel $\mathrm{X}_{4}$ sebesar 0,336 dan bertanda positif, ini menunjukkan bahwa Budaya mempunyai hubungan yang searah dengan Keputusan Pembelian. Hal ini mengandung arti bahwa setiap kenaikan Budaya satu satuan maka variabel Keputusan Pembelian (Y) akan naik sebesar 0,336 dengan asumsi bahwa variabel bebas yang lain dari model regresi adalah tetap.

\subsection{Pembahasan}

Berdasarkan hasil uji hipotesis menyatakan bahwa Atribut, Manfaat, Nilai dan Budaya secara bersama-sama berpengaruh positif dan signifikan terhadap Keputusan Pembelian Sabun Cuci Rinso, sedangkan secara parsial hanya variabel Nilai yang tidak berpengaruh secara signifikan terhadap Keputusan Pembelian Sabun Cuci Rinso. Menurut analisa penulis, sebab dari variabel Nilai tidak berpengaruh terhadap Keputusan Pembelian dikarenakan oleh tidak sesuainya harga dengan kualitas produk.

Berdasarkan hasil uji koefisien determinasi, didapatkan hasil bahwa variabel Atribut, Manfaat, Nilai dan Budaya mempegaruhi Keputusan Pembelian Sabun Cuci Rinso hanya sebesar 41,2\%. Menurut analisa penulis, hal ini disebabkan oleh kurangnya variabel dari brand image yang digunakan oleh penulis. Pada penelitian ini penulis hanya menggunakan empat dari enam variabel yang dimiliki oleh brand image yaitu variabel Atribut, Manfaat, Nilai dan Budaya, sedangkan variabel yang tidak digunakan adalah variabel Kepribadian dan Pemakai. 


\section{Kesimpulan}

\subsection{Kesimpulan}

Berdasarkan hasil penelitian dan pengolahan data yang diperoleh melalui penyebaran kuesioner kepada responden sebanyak 267 angket kuesioner mengenai pengaruh citra produk Sabun Cuci Rinso terhadap keputusan pembelian konsumen, maka penulis menarik kesimpulan sebagai berikut:

1. Berdasarkan pengujian secara serempak/simultan (Uji F), ternyata hasil penelitian membuktikan bahwa semua variabel citra produk (Atribut, Manfaat, Nilai dan Budaya) dari variabel citra produk secara simultan mempunyai pengaruh yang signifikan terhadap variabel dependen, yaitu Keputusan Pembelian.

2. Berdasarkan analisis secara parsial (Uji t), ternyata hasil penelitian membuktikan bahwa tiga variabel dari variabel independen citra produk yaitu Atribut, Manfaat dan Budaya mempunyai pengaruh positif dan signifikan terhadap variabel dependen yaitu keputusan pembelian dan satu variabel dari variabel independen yaitu Nilai tidak mempunyai pengaruh yang signifikan terhadap keputusan pembelian Sabun Cuci Rinso, adapun penjelasannya sebagai berikut:
a. Variabel Atribut berpengaruh secara signifikan terhadap keputusan pembelian.
b. Variabel Manfaat berpengaruh secara signifikan terhadap keputusan pembelian.
c. Variabel Budaya berpengaruh secara signifikan terhadap keputusan pembelian.
d. Variabel Nilai tidak berpengaruh secara signifikan terhadap keputusan pembelian.

3. Perhitungan koefisien determinasi menunjukkan besarnya pengaruh variabel X (brand image) terhadap variabel Y (keputusan pembelian), berarti bahwa nilai koefisien determinasi yang penulis dapatkan sebesar 41,2\% merupakan besarnya pengaruh brand image terhadap keputusan pembelian. Sedangkan sisanya 58,8\% dipengaruhi oleh faktor lain yang tidak diukur dalam penelitian ini.

\subsection{Keterbatasan Penelitian}

Dalam penelitian ini tentunya tidak lepas dari kekhilafan serta kekurangan, meskipun telah penulis upayakan semaksimal mungkin untuk mencapai kesempurnaan dengan menghindari dan mengurangi hal-hal yang kurang baik. Keterangan yang penulis berikan diantaranya adalah :

1. Sampel penelitian ini hanya khusus untuk STEI Tazkia, Universitas Pakuan dan Universitas Djuanda di kota Bogor. 
2. Penelitian ini hanya menggunakan metode regresi linear berganda.

3. Penulis hanya menguji empat dari enam variabel citra produk.

\subsection{Saran}

Berdasarkan hasil penelitian, maka penulis memiliki pandangan atau saran yang mungkin dapat dijadikan sebagai bahan masukan untuk perkembangan selanjutnya terlebih kepada pihak-pihak yang bersangkutan. Adapun saran tersebut diantaranya adalah:

1. Penulis berharap Perusahaan Unilever untuk dapat mengkaji ulang tentang hal Citra Merek Sabun Cuci Rinso. Dalam memilih suatu produk, biasanya konsumen bukan hanya melihat dari kualitas produk itu sendiri, tetapi konsumen juga Citra merek tersebut, sehingga secara tidak langsung hal ini dapat mempengaruhi proses keputusan pembelian konsumen.

2. Untuk mahasiswa dan civitas akademik yang akan meneliti tentang citra produk, penulis menyarankan agar menggunakan keseluruhan variabel dari citra produk, yaitu: Atribut, Manfaat, Nilai, Budaya sehingga mencapai hasil maksimal.

\section{Referensi:}

Arikunto S, 2006. Prosedur Penelitian Suatu Pendekatan Praktik, Ed Revisi VI. Penerbit PT Rineka Cipta, Jakarta.

Erlina, 2008. Metodologi Penelitian Bisnis untuk Akuntansi dan Manajemen. Edisi Kedua. USU Press, Medan.

Ghozali, Imam. 2005. Aplikasi Analisis Multivariate dengan program SPSS. Badan Penerbit Universitas Diponegoro, Semarang.

Kinnear, Thomas C, dan Taylor, James R., (1998). Riset Pemasaran, Edisi tiga, Jakarta: Erlangga.

Keller, Kevin Lane. 1998. Strategic Brand Management, Building, Measuring, and Managing Brand Equity. Prentice Hall. New Jersey.

Kotler, Philip. 2004. Manajemen Pemasaran. Edisi Kesepuluh. Diterjemahkan oleh Benyamin Molan. Jilid 1. Jakarta : Indeks.

Kotler, Philip. 2003. Manajemen Pemasaran. Edisi Kesepuluh. Diterjemahkan oleh Benyamin Molan. Jilid 1. Jakarta : Indeks.

Nazir, Moh. 2005. Metode Penelitian. Cetakan Pertama. Penerbit Ghalia

Stanton, William J. 2001. Prinsip Pemasaran. Erlangga. Jakarta.

Stanton, William J. 1996. Prinsip Pemasaran. Erlangga. Jakarta.

Sugiyono, 1999. Metode Penelitian Bisnis. Alfabeta. Bandung.

Sugiyono, 2009. Metode Penelitian Kuantitatif, Kualitatif, dan R\&D. Alfabeta.

(unilever.co.id) 